\title{
Monocanalicularis szilikonsztent implantációja könnycsatorna-elzáródással született gyermekekben ${ }^{*}$
}

\author{
Szalai Irén dr. - Maneschg Otto Alexander dr. - Nagy Zoltán Zsolt dr. \\ Semmelweis Egyetem, Általános Orvostudományi Kar, Szemészeti Klinika, Budapest
}

Bevezetés: Csecsemőkorban a könnyezés gyakori oka a könnycsatorna veleszületett elzáródása, mely az esetek nagy részében 1 éves korra spontán oldódik.

Célkitüzés: Retrospektív tanulmányunk célja a monocanalicularis szilikonsztent (Masterka ${ }^{\circledR}$ ) implantációjával kapcsolatos eredményeink bemutatása.

Módszer: 2015. január 1. és 2020. január 30. között monocanalicularis szilikonsztent implantációján átesett gyermekek adatait dolgoztuk fel. Bevonási kritériumként szerepelt a legalább 6 hónapja fennálló, konzervatív kezelésre nem szúnő könnyezés és emiatt előzetesen elvégzett szondázás, mely után a panaszok kiújultak. Kizárási kritérium volt a csontosan elzárt ductus nasolacrimalis és a hibás szemhéjállás. A mútét hatékonyságát a szilikonsztent eltávolítását követő legalább 2 hónap panaszmentességgel definiáltuk.

Eredmények: 25 gyermek (10 lány [40\%] és 15 fiú [60\%]) összesen 30 szemén végeztünk szilikonsztent-beültetést. Az átlagéletkor 4,92 $\pm 3,03$ év $(1,5-12$ év, $\mathrm{n}=25)$ volt. Minden páciens a születése óta könnyezett. A mútét előtt váladékképződést $20(66,67 \%, \mathrm{n}=30)$, krónikus szemhéj- és kötőhártya-gyulladást $10(33,33 \%, \mathrm{n}=30)$ esetben észleltünk. Tompalátást, jelentőss astigmiát nem találtunk. A sztentet átlagosan 3,5 $\pm 1,0(\mathrm{n}=30)$ hónap után távolítottuk el. A mútétet követően 1 héttel $24(80 \%, \mathrm{n}=30), 3$ hónappal $28(93,33 \%, \mathrm{n}=30)$ és 6 hónappal $24(88,89 \%$, $\mathrm{n}=27)$ szem volt tünetmentes.

Következtetés: A Masterka ${ }^{\circledR}$ implantációja egyszerúen kivitelezhető, kifejezetten hatékony módszer lehet az 1 évnél idősebb gyermekek veleszületett könnycsatorna-szúkületének megoldására, különösen olyan esetekben, amikor a korábbi szondázás nem vezetett eredményre, valamint hosszabb szakaszon észlelünk szúkületet. Ez utóbbi esetekben megfontolandó lenne a primer szilikonsztent-implantáció is.

Orv Hetil. 2020; 161(48): 2037-2042.

Kulcsszavak: veleszületett könnycsatorna-elzáródás, gyermek, monocanalicularis szilikonsztent

\section{Monocanalicular silicone stent implantation in children with congenital nasolacrimal duct obstruction}

Introduction: Congenital nasolacrimal duct obstruction is a common cause of epiphora in infants. In most cases, spontaneous resolution occurs by 1 year of age.

Objective: Retrospective evaluation of clinical outcomes of monocanalicular lacrimal duct stent implantation (Masterka $\left.^{\circledR}\right)$.

Method: Data of patients undergoing monocanalicular silicone stent implantation between lst January 2015 and 30th January 2020 were evaluated. Inclusion criteria were resistant tearing to conservative therapy which had been persisting at least for 6 months, and previous probing did not resolve the symptoms. Exclusion criteria were associated bony obstruction or eyelid malposition. Treatment success was defined as complete resolution of epiphora at least two months after the procedure.

Results: Implantation was performed on 30 eyes of 25 children (10 females [40\%] and 15 males [60\%]). The mean age was $4.92 \pm 3.03$ years $(1.5-12$ years, $\mathrm{n}=25)$. Epiphora was a persistent symptom in every patient since birth. Preoperatively, discharge was observed in $20(66.6 \%, \mathrm{n}=30)$ patients, while chronic blepharitis and conjunctivitis occurred in $10(33.33 \%, \mathrm{n}=30)$ children. Amblyopia or significant astigmatism was not observed in any case. Stent was removed after $3.5 \pm 1.0(\mathrm{n}=30)$ months. At one week postoperatively $24(80 \%, \mathrm{n}=30)$, at 3 months 28 $(93.33 \%, \mathrm{n}=30)$ and at 6 months $24(88.89 \%, \mathrm{n}=27)$ eyes were asymptomatic.

\footnotetext{
*A tanulmány poszterként részben bemutatásra került a 44. European Paediatric Ophthalmological Society (EPOS, 2018. szeptember 7-9., Budapest) kongresszuson.
} 
Conclusion: Implantation of monocanalicular silicone stent is effective and easy-to-perform. It can resolve congenital tear duct stenosis, especially where previous probing was not successful and where stenosis is longer or occurs in several localizations. In the latter cases, primary stent implantation should be considered.

Keywords: congenital nasolacrimal duct obstruction, child, monocanalicular silicone stent

Szalai I, Maneschg OA, Nagy ZZ. [Monocanalicular silicone stent implantation in children with congenital nasolacrimal duct obstruction]. Orv Hetil. 2020; 161(48): 2037-2042.

(Beérkezett: 2020. május 15.; elfogadva: 2020. június 20.)

\section{Rövidítések}

$\mathrm{CNLDO}=($ congenital nasolacrimal duct obstruction $)$ veleszületett ductus nasolacrimalis elzáródás; DCR = dacryocystorrhinostomia

A csecsemőkori epiphora leggyakoribb oka a könnyutak veleszületett szúküilete, elzáródása (CNLDO). A páciensek tünetei között a könnyezés mellett a könnyzacskó masszázsa során jelentkező könny vagy genny regurgitatiója, a pillákon megjelenő váladék és a szemhéjak irritációja, kipirosodása szerepel [1,2]. A könnyelvezetés zavara nemcsak állandó diszkomfortérzést okoz a páciensnek, hanem látásromlást is előidézhet. Egyes tanulmányok szerint elhanyagolt vagy fel nem ismert esetben hosszú távon irreguláris astigmiához, illetve tompalátás kialakulásához vezethet a szemrésben megrekedt könny, hiszen sokszor a látásfejlődés legérzékenyebb időszakában változtathatja meg a fénytörést a magas könnytócsa [3-7]. Mások azonban megkérdőjelezik az epiphora okozta deprivatiós amblyopia kialakulásának lehetóségét, mivel a korban megfeleló átlagpopulációhoz képest a könnyező páciensek között nem találtak nagyobb arányban tompalátókat $[8,9]$.

A könnyelfolyási akadály az újszülöttek kb. 5-30\%ánál okoz panaszt [10-14]. Ugyanakkor csak kb. 2-4\%-uknál állandósul, nagy részüknél spontán vagy konzervatív terápiára rendeződik $[1,13,15-19]$. A könnycsatorna-elzáródással születettek kb. 0,1\%-ánál congenitalis dacryocystokele is kialakulhat, mely fájdalommal járhat, és sürgős beavatkozást igényel [15]. MacEwen és mtsa 1 hónapos újszülöttek 95\%-ánál észleltek könnyezést, mely azok nagy részénél azonban az első hónapokban megszűnt, majd l éves korukra 96\%-uk tünetmentessé vált [14]. Amennyiben a konzervatív terápia (könnyzacskómasszázs, gyulladás esetén antibiotikum használata) nem hoz megoldást, a könnycsatorna szondázásával rendszerint oldható a szúkület vagy elzáródás. Azokban az esetekben, amikor a könnycsatorna megnyitható, de szondázást követően is fennállnak a tünetek, a szúkület mértékétől függően szóba jöhet ismételt szondázás, a könnycsatorna ballonos tágítása vagy szilikonsztent implantációja, súlyos esetben pedig dacryocystorrhinostomia (DCR) végzése $[2,20,21]$. Habár a szondázás többször megismételhető, a többszöri pró- bálkozás megnövelheti az álútképzés, a granuláció, a heges szúkület kialakulásának lehetőségét $[2,10,11]$. Napjainkban már többféle szilikonsztent létezik a könnycsatorna különböző szakaszain lévő szúkületek kezelésére [22]. A ductus nasolacrimalis tágítására az egyik legpraktikusabb eszköz a fémvezetőt is tartalmazó monocanalicularis szilikonsztent. A hajlékony intubációs csövekkel szemben nagy előnye, hogy a fémvezető segítségével a rugalmas és hajlékony implantátum a szúkebb szakaszokon is könnyebben átvezethető [21].

Jelen közleményünkben a konzervatív kezelésre, valamint az előzetes szondázásra nem javuló, veleszületett könnycsatorna-elzáródás miatt végzett monocanalicularis szilikonsztent-implantáció eredményeit foglaltuk össze.

\section{Módszer}

Vizsgálatainkat a Helsinki Deklaráció elveinek megfelelően végeztük. Retrospektív tanulmányunkban a Semmelweis Egyetem Szemészeti Klinikáján 2015. január 1. és 2020. január 30. között veleszületett könnycsatornaelzáródás miatt 35 mm-es Masterka ${ }^{\circledR}$ (FCI, Párizs, Franciaország, CE 0459) monocanalicularis szilikonsztent beültetésén átesett gyermekek adatait dolgoztuk fel. Minden páciens spontán, illetve konzervatív terápiára (könnytömlőmasszázs) nem javuló epiphora miatt előzetesen már átesett könnycsatorna-szondázáson, melynek során elzárt, de megnyitható, illetve szúkebb, de szondázható csatornát találtunk, és a szondázást követő 2 hónapon belül nem váltak tünetmentessé. A jelen tanulmányból kizártuk azokat a gyermekeket, akiknél csontosan elzárt ductus nasolacrimalist vagy szemhéjállási hibát észleltünk. Minden beválogatott páciens legalább 6 hónapja könnyezett. A beavatkozást minden esetben narkózisban végeztük, melynek során az alsó vagy felső canaliculuson keresztül monocanalicularis szilikonsztentet implantáltunk a ductusba, attól függően, hogy melyik canaliculus volt szúkebb. A fémvezetőt is tartalmazó eszköz a ductus nasolacrimalis teljes hosszában, így a - sok esetben a könnyezést magyarázó - perzisztáló Hasnerbillentyü területére is levezethető (1-3. ábra). A szilikonsztent proximalis végén lévő kiszélesedő talp segíti az 


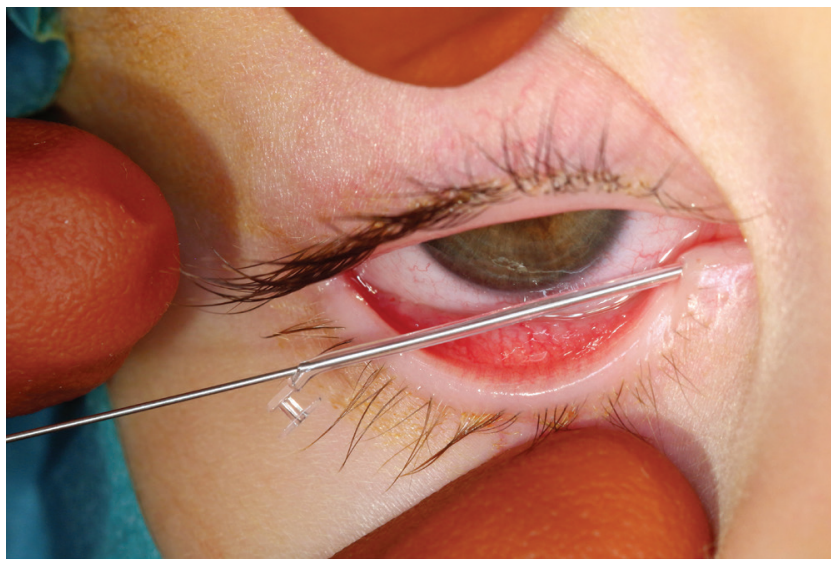

l. ábra $\mid$ Monocanalicularis szilikonsztent bevezetése az alsó könnyponton keresztül

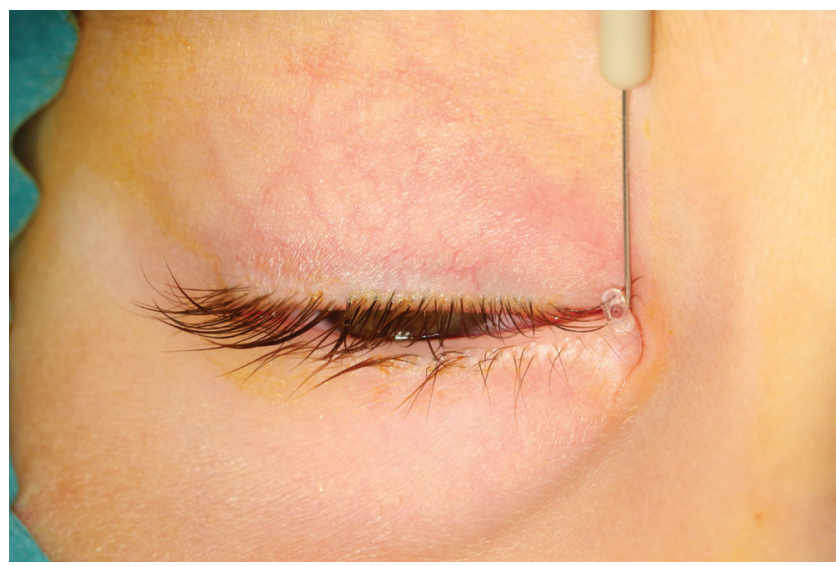

2. ábra A szilikonsztent fémvezetőjének segítségével a szúk ductus na-
solacrimalisba is bevezethetô a hajlékony implantátum

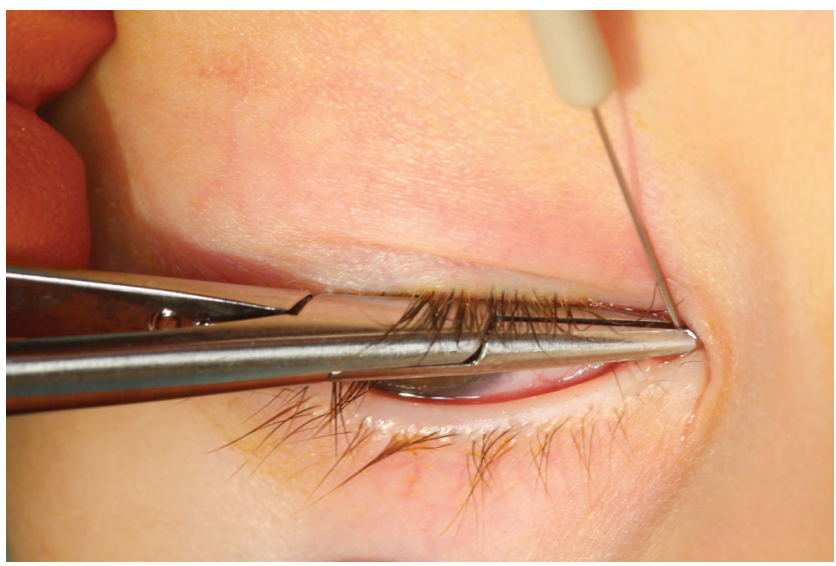

3. ábra Túfogó segítségével a szilikonsztent pozíciójának stabilizálása a
fémvezetố eltávolítása közben

eszköz stabil illeszkedését a könnypontba, meggátolva a szilikonsztent kimozdulását (4. ábra).

A mütét után 1 hétig naponta $5 \times$ tobramycin/dexametazon $(3 \mathrm{mg} / \mathrm{ml}$ tobramycin és $1 \mathrm{mg} / \mathrm{ml}$ dexametazon) kombinált szemcseppterápiát alkalmaztunk. A jelen tanulmányban a mütét utáni 1 hetes, 3 hónapos és 6 hónapos ellenőrző vizsgálatok eredményeit dolgoztuk

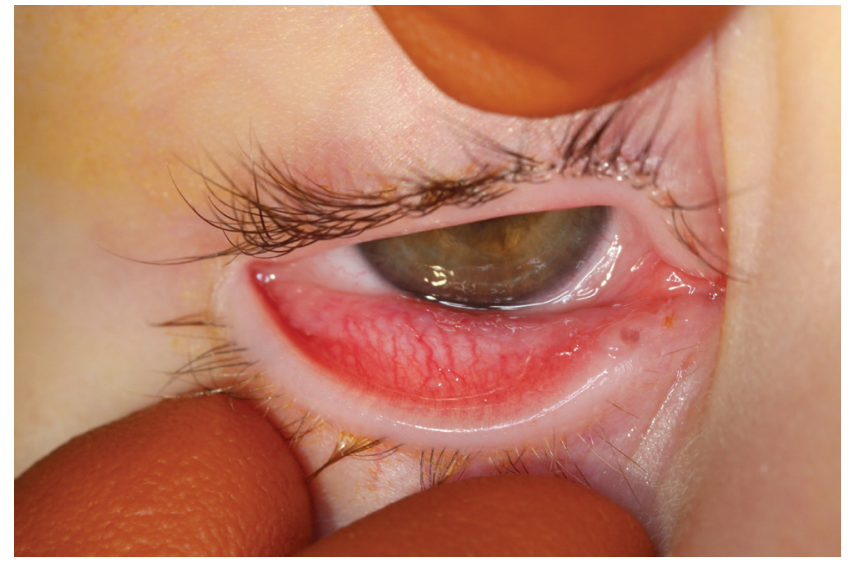

4. ábra

Az alsó könnypontban stabilan ül a szilikonsztent talpa, mely nem okoz panaszt a páciensnek

fel. A szilikonsztent eltávolítása helyi érzéstelenítésben, csipesz segítségével történt. A beavatkozást akkor tekintettük eredményesnek, ha a szilikonsztent-eltávolítást követő 2 hónapban a páciensnél nem jelentkezett könynyezés és/vagy váladék.

\section{Eredmények}

Tanulmányunkban 25 gyermeknél, 10 lánynál (40\%) és 15 fiúnál (60\%), összesen 30 sztentbeültetést végeztünk. Öt (20\%) kétoldali, 12 (48\%) bal oldali, 8 (32\%) jobb oldali mütét történt. A gyermekek átlagéletkora 4,92 \pm 3,03 év (1,5-12 év, $\mathrm{n}=25)$ volt. A posztoperatív 1. héten és a 3. hónapos kontrollvizsgálaton minden bevont páciens részt vett (25 gyermek). Az utolsó ellenőrző vizsgálaton 23 gyermek jelent meg. Így 30 mútét eredményeit összesítettük az 1 . heti és a 3 . hónapos vizsgálat esetén, míg 27 mútét eredményének adatait dolgoztuk fel a 6 hónapos vizsgálati időpontban (5. ábra).

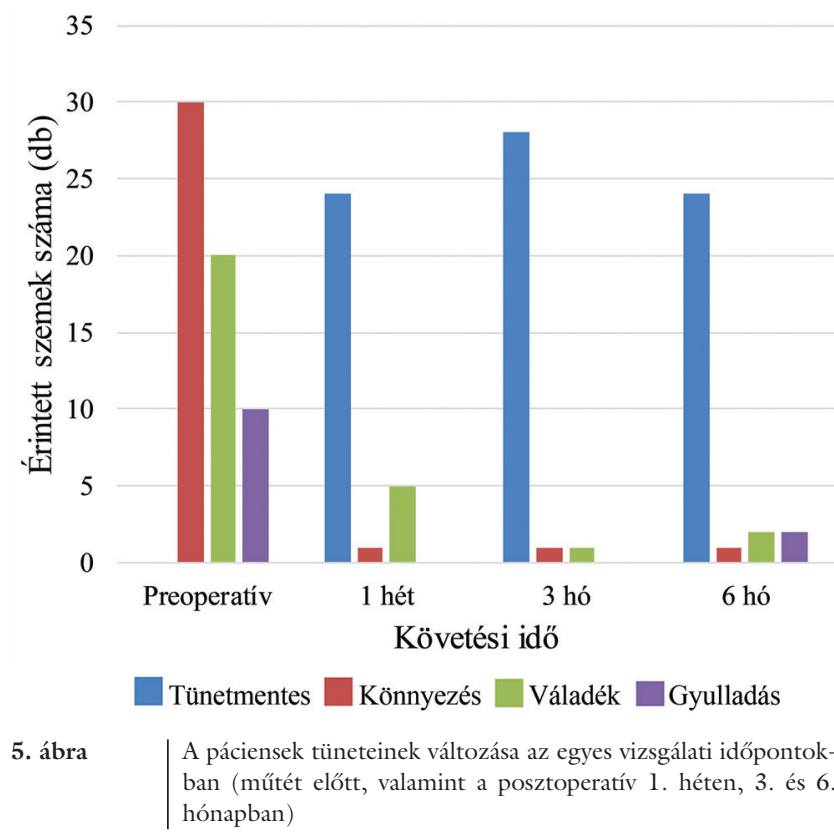


Minden páciens könnyezése a születés óta fennállt. A mütét előtt 20 esetben $(66,67 \%, \mathrm{n}=30)$ észleltünk váladékképződést, valamint 10 gyermeknél $(33,33 \%, \mathrm{n}=30)$ krónikus szemhéj- és kötőhártya-gyulladást. A vizsgált szemek esetében nem találtunk tompalátást vagy jelentős astigmiát. Az átlagos szférikus ekvivalens $+0,11 \pm 1,20 \mathrm{D}$ ( $\mathrm{n}=30$ ) volt, melyet cycloplegiában mértünk a kezelést megelőzően az első megjelenéskor. Egyéb szemészeti eltérést egyik páciensnél sem észleltünk. A szilikonsztent $24(80 \%, \mathrm{n}=30)$ esetben az alsó, $6(20 \%, \mathrm{n}=30)$ esetben a felső canaliculusba került. A műtét során, illetve a korai posztoperatív időszakban egy esetben sem észleltünk szövődményt. A beavatkozást követően az összes gyermek könnyezése csökkent vagy teljesen megszűnt. A mütét után 1 héttel $24(80 \%, \mathrm{n}=30), 3$ hónappal 28 $(93,33 \%, \mathrm{n}=30)$ és 6 hónappal $24(88,89 \%, \mathrm{n}=27)$ szem volt tünetmentes. A szilikonsztent eltávolítására a mútétet követően átlagosan 3,5 $\pm 1,0(\mathrm{n}=30)$ hónap múlva került sor. 2 gyermeknél a szilikonsztent idő előtt kiesett (2 hét, illetve 2,5 hónap után kidörzsölték). Ezenkívül a teljes követési idő alatt szövődményt nem észleltünk. Azon páciensek anamnézisében, akik továbbra is könnyeztek, herpes simplex conjunctivitis és blepharitis ( 1 fó), Goldenhar-szindróma ( 1 fó), illetve többszöri szondázás és diffúzan szúk ductus nasolacrimalis ( 1 fó) szerepelt.

\section{Megbeszélés}

Jelen tanulmányunk célja a veleszületett könnycsatornaelzáródás miatt végzett monocanalicularis szilikonsztentimplantációval szerzett tapasztalataink összefoglalása volt.

A csecsemőkori könnyezés kb. 90\%-a 12 hónapos korra spontán vagy konzervatív terápiára megoldódik [1, 23]. A könnycsatorna szondázása az esetek nagy részében (70-97\%) megoldja a panaszokat, és nincs szükség további beavatkozásra, ugyanakkor 3 éves kor felett ez az arány lecsökken (78-79\%) [13, 23-25]. Az epiphorát okozó mechanikai akadály sok esetben a Hasnerbillentyú szintjében perzisztáló membrán, de előfordulhat csontos szúkület a canalis nasolacrimalis vagy a meatus inferior területén is $[2,26,27]$. Lorena és mtsai a koraszülöttek körében magasabb CNLDO-incidenciát találtak az időre született páciensekhez képest (16\% vs. $3,5 \%)$ [28], ezt magyarázhatja a könnycsatorna még inkomplett kanalizációja [28, 29]. A szondázásra nem javuló ductus nasolacrimalis szúkületek esetében többféle szilikonsztent implantációját vagy ballonkatéteres tágítást is alkalmazhatunk. A veleszületett könnycsatornaszúkületek megoldásában a két eljárás hatékonysága hasonló (62-100\% vs. 79-96\%), társuló canaliculus lacrimalis szúkület esetén azonban a ballonos tágítás kevésbé eredményes [1, 1 1, 21 1, 30-39]. A szilikonsztentek közül a fémvezetővel ellátott Masterka ${ }^{\circledR}$ alkalmazása könnyü, és az elérhető méretekből megfelelően választva a ductus nasolacrimalis teljes hosszában képes azt tágítani, sőt a canaliculus lacrimalis szúkületeire is hatással van [21]. A monocanalicularis szilikonsztent-implantáció jelen tanulmányunkban az összes páciens könnyezését csökkentette, és $88,89 \%$-ban meg is szüntette. A továbbra is könnyező gyermekek anamnézisében szereplő vírusos kötőhártya-gyulladás, egyes arcfejlődési rendellenességek, a gyakran megismételt könnycsatorna-szondázás, illetve a diffúz ductus nasolacrimalis vagy a canaliculus lacrimalis szúkület ronthatja a mütéti hatékonyságot. A Pediatric Eye Disease Investigator Group 2008-ban 182 gyermek esetét felölelő tanulmányában a primer intubáció 90\%-ban bizonyult eredményesnek, melyek 70\%-a monocanalicularis implantátum volt. Engel és mtsai 96\%-ban (2 éves kor felett 90\%-ban) [35], Elsawaby $83 \%$-ban (25 eset) [25], míg a Masterka ${ }^{\circledR}$ kidolgozója, Fayet $85 \%$-ban (110 szem) találta hatékonynak az eljárást [34]. A tanulmányok eredményei közötti különbségek adódhatnak a különböző esetszámokból, az életkorokból, a különféle kizárási és beválogatási kritériumokból vagy az eltérő típusú szilikoncsövekból is. Napjainkban a jó eredmények és a komplikációk alacsony száma [35] miatt egyes szerzők a 18 hónapos kor felett elsődlegesen választandó módszerként ajánlják a szilikonsztent-implantációt [11], tekintettel arra, hogy a szondázások sikeressége az életkorral kimutathatóan csökken [1, 33, 39, 40], valamint arra, hogy a csecsemók egy részénél észlelhető anatómiai eltérések miatt valószínúleg nem tud spontán vagy szondázásra oldódni a szúkület [24, 41]. Mások szerint a primer szilikonsztent-implantáció megakadályozhatja a könnycsatorna-szondázás során minor traumából eredő esetleges epithelsérüléseket, -vérzéseket, melyek heges szúkületek kialakulásához vezethetnének [25, 41, 42]. Már egyetlen sikertelen szondázás után is canaliculus lacrimalis szúkület alakulhat ki [43]. Ugyanakkor a monocanalicularis szilikonsztent implantációjával kapcsolatos szövődmények száma elenyésző $[33,35]$. Elvétve előfordulhat a könnypont elongációja, a szilikonsztent distalis vagy proximalis irányú elmozdulása, mely a ductus nasolacrimalis elzáródását, cornea erosiot, keratitist, conjunctivitist okozhat. Ilyen esetekben a szilikonsztent idő előtti eltávolítása szükséges [33, 37-39]. Az explantáció idejére egyelőre nincs egységes ajánlás az irodalomban, az egyes szerzők általában 6 hét és 18 hónap közt javasolják [1, 33, 44-46]. A tanulmányok többsége ideálisnak a 3 hónapot jelölte meg [22], esetleg diffúz ductus nasolacrimalis szúkület, társuló canaliculusszűküulet esetén hosszabb időtartamot. Napjainkban az explantáció idejét néhányan 1 hónap után javasolják; Fayet szerint 1 hónap után a hatékonyság nem nő, ugyanakkor a lehetséges szövődmények elkerülhetők $[34,47]$. Peterson és mtsai azt is kimutatták, hogy 24 hónapos kor alatt a mútét hatékonyságát nem rontja, ha a szilikonsztent a tervezett 31 . nap előtt kiesik (17\% vs. 18\% könnyezett), ugyanakkor a 2 évnél idősebb pácienseknél már rontja ezt az arányt (39\% vs. 19\% könnyezett) [38]. Tanulmányunkban a sztentexplantációra átlagosan 3,5 \pm 1,0 hónap után került sor. Két gyermeknél 
csúszott ki 3 hónapnál hamarabb a szilikoncső, azonban egyiküknél sem alakult ki ismételten könnyezés. Egyéb posztoperatív szövődményt nem észleltünk. Nehezen kivitelezhető esetekben (például diffúz szúküuleteknél) - ahogy szondázáskor is - igyekeznünk kell az álútképzés lehetőségét elkerülni. Ehhez segítséget nyújthat fül-orrgégész kollégákkal együttmúködve az endonasalis vizualizáció [1], ugyanakkor gyakorlott kezekben a módszer biztonságosan elvégezhető e nélkül is. A módszer másik nehézsége lehet, hogy a fémvezető eltávolításakor a fémmel együtt nem húzzuk-e vissza a szilikonsztentet is; ennek elkerülésére javasolt a talpat ellentartó eszköz időnkénti felengedésével ellenőrizni, hogy nem indul-e visszafelé a szilikonsztent is (3. ábra). A beavatkozás kifejezetten rövid ideig tart; nagy előnye, hogy nem szükséges mély altatás, maszkos narkózisban is elvégezhető, míg a szilikoncső eltávolításához nincs szükség altatásra, egy csipesz segítségével könnyedén kihúzható. Nincs varratbehelyezés, mivel a sztent talpa stabilan illeszkedik a könnypontban [1].

A Masterka ${ }^{\circledR}$ szilikonsztent jelenleg a társadalombiztosítás által nem finanszírozott eszköz, mely a páciensek számára kb. 40000 Ft anyagi megterhelést jelent. Egyedi méltányossági támogatás a Nemzeti Egészségbiztosítási Alapkezelőtől kérvényezhető.

\section{Következtetés}

A fémvezetővel ellátott monocanalicularis szilikonsztentimplantáció a szondázásra nem oldódó könnycsatorna szúkület/elzáródás esetében kifejezetten hatékony, minimálisan invazív eljárás, mely kisgyermekek esetében is könnyedén, gyorsan kivitelezhető. Hatására pácienseink közel 88,89\%-ánál megszűntek a tünetek. Az eljárás okozta szövődmények lehetősége elenyésző, jelen tanulmányunkban nem tapasztaltunk lényeges szövődményt. A ballonkatéteres könnycsatorna-tágítással szemben canaliculus lacrimalis szúkület esetén is megoldást nyújthat, a dacryocystorhinostomiánál jóval kisebb megterhelést jelent, és a sztent eltávolítása helyi érzéstelenítésben elvégezhető. Véleményünk szerint a rosszabbul reagáló, ismételt elzáródásra hajlamos, kifejezett vagy diffúz szükületeknél az 1 évesnél idősebb gyermekek esetében már az első szondázás alkalmával megfontolandó a Masterka ${ }^{\circledR}$ primer implantációja, mely így több héten vagy hónapon át tágíthatja az érintett könnycsatornaszakaszt, csökkentve ezzel az ismételt beavatkozáshoz szükséges altatásnak vagy a szondázás által esetlegesen kiváltott hegesedési hajlamnak a lehetséges kockázatát.

Anyagi támogatás: A közlemény megírása, illetve a kapcsolódó kutatómunka anyagi támogatásban nem részesült.

Szerzôi munkamegosztás: Koncepció és tervezés: Sz. I., M. O. A. A kézirat elkészítése: Sz. I. A mütétek elvég- zése: Sz. I., M. O. A. Adatgyüjtés: Sz. I., M. O. A. Adatfeldolgozás: Sz. I. Szakmai véleményezés: N. Z. Zs., M. O. A. A kézirat felülvizsgálata: N. Z. Zs. A cikk végleges változatát valamennyi szerző elolvasta és jóváhagyta.

Érdekeltségek: A szerzőknek nincsenek érdekeltségeik.

\section{Köszönetnyilvánítás}

Az első szerző köszönetet mond Széles Évának a fotók elkészítéséért és dr. Csorba Anitának az önzetlen segítségéért.

\section{Irodalom}

[1] Vagge A, Ferro Desideri L, Nucci P, et al. Congenital nasolacrimal duct obstruction (CNLDO): a review. Diseases 2018; 6: 96.

[2] Berta A. Pathologies of the lacrimal system. In: Süveges I. (ed.) Ophthalmology. [A könnyszervek betegségei. In: Süveges I. (szerk.) Szemészet.] Medicina Könyvkiadó, Budapest, 2015; pp. 329-342. [Hungarian]

[3] Ramkumar VA, Agarkar S, Mukherjee B. Nasolacrimal duct obstruction: does it really increase the risk of amblyopia in children? Indian J Ophthalmol. 2016; 64: 496-499.

[4] Eshraghi B, Akbari MR, Fard MA, et al. The prevalence of amblyogenic factors in children with persistent congenital nasolacrimal duct obstruction. Graefes Arch Clin Exp Ophthalmol. 2014; 252: 1847-1852.

[5] Badakere A, Veeravalli TN, Iram S, et al. Unilateral congenital nasolacrimal duct obstruction and amblyopia risk factors. Clin Ophthalmol. 2018; 12: 1255-1257.

[6] Kipp MA, Kipp MA Jr, Struthers W. Anisometropia and amblyopia in nasolacrimal duct obstruction. J AAPOS 2013; 17: 235238.

[7] Siddiqui SN, Mansoor H, Asif M, et al. Comparison of anisometropia and refractive status in children with unilateral and bilateral congenital nasolacrimal duct obstruction. J Pediatr Ophthalmol Strabismus 2016; 53: 168-172.

[8] AlHammad F, Al Tamimi E, Yassin S, et al. Unilateral congenital nasolacrimal duct obstruction, is it an amblyogenic factor? Middle East Afr J Ophthalmol. 2018; 25: 156-160.

[9] Vagge A, Tulumello C, Pellegrini M, et al. Amblyopia risk factors in newborns with congenital nasolacrimal duct obstruction. J Pediatr Ophthalmol Strabismus 2020; 57: 39-43.

[10] Kapadia MK, Freitag SK, Woog, JJ. Evaluation and management of congenital nasolacrimal duct obstruction. Otolaryngol Clin North Am. 2006; 39: 959-977.

[11] Takahashi Y, Kakizaki H, Chan WO, et al. Management of congenital nasolacrimal duct obstruction. Acta Ophthalmol. 2010; 88: 506-513.

[12] Young JD, MacEwen CJ. Managing congenital lacrimal obstruction in general practice. BMJ 1997; 315: 293-296.

[13] Robb RM. Success rates of nasolacrimal duct probing at time intervals after 1 year of age. Ophthalmology 1998; 105: 13071310 .

[14] MacEwen CJ, Young JD. Epiphora during the first year of life. Eye 1991; 5: 596-600.

[15] Britto FC, Rosier VV, Luz TV, et al. Nasolacrimal duct mucocele: case report and literature review. Int Arch Otorhinolaryngol. 2015; 19: 96-98.

[16] Marr JE, Drake-Lee A, Willshaw HE. Management of childhood epiphora. Br J Ophthalmol. 2005; 89: 1123-1126.

[17] Kakizaki H, Takahashi Y, Kinoshita S, et al. The rate of symptomatic improvement of congenital nasolacrimal duct obstruction in Japanese infants treated with conservative management during the 1st year of age. Clin Ophthalmol. 2008; 2: 291-294. 
[18] Hung CH, Chen YC, Lin SL, et al. Nasolacrimal duct probing under topical anesthesia for congenital nasolacrimal duct obstruction in Taiwan. Pediatr Neonatol. 2015; 56: 402-407.

[19] Le Garrec J, Abadie-Koebele C, Parienti JJ, et al. Nasolacrimal duct office probing in children under the age of 12 months: cure rate and cost evaluation. J Fr Ophtalmol. 2016; 39: 171-177.

[20] Szalai I. Surgeries of lacrimal pathway and their instruments. In: Nagy ZZ. (ed.) Knowledge of ophthalmic diagnostics and surgery. [Könnyútmútétek és múszerei. In: Nagy ZZs. (szerk.) Szemészeti diagnosztikai és mútéttani ismeretek.] Semmelweis Egyetem Egészségtudományi Kar, Budapest, 2019; pp. 270280. [Hungarian]

[21] Szalai I. Pathologies and treatments of the lacrimal pathway. [Könnyelvezetési zavarok és kezelésük.] Szemészet 2019; 156 242-256. [Hungarian]

[22] Lukáts O, Resch M, Kusnyerik Á, et al. Implants in ophthalmology (from punctum plug to retinal chip). [Implantátumok a szemészetben (a punctum plug-tól a retina chip-ig).] Orvosképzés 2014; 89: 89-90. [Hungarian]

[23] Repka MX, Chandler DL, Beck RW, et al. Primary treatment of nasolacrimal duct obstruction with probing in children younger than 4 years. Ophthalmology 2008; 115: 577-584.e3.

[24] Skuta G, Cantour L, Weiss J. Pediatric ophthalmology and strabismus. In: Basic and clinical science course. American Academy of Ophthalmology, San Francisco, CA, 2011.

[25] Elsawaby EA, El Essawy RA, Abdelbaky SH, et al. Pushed monocanalicular intubation versus probing as a primary management for congenital nasolacrimal obstruction. Clin Ophthalmol. 2016 10: 1487-1493

[26] Petersen RA, Robb RM. The natural course of congenital obstruction of the nasolacrimal duct. J Pediatr Ophthalmol Strabis mus 1978; 15: 246-250.

[27] Moscato EE, Kelly JP, Weiss A. Developmental anatomy of the nasolacrimal duct: implications for congenital obstruction. Ophthalmology 2010; 117: 2430-2434.

[28] Lorena SH, Silva JA, Scarpi MJ. Congenital nasolacrimal duct obstruction in premature children. J Pediatr Ophthalmol Strabismus 2013; 50: 239-244.

[29] Szalai I. Disorders of the tear production and drainage system. In: Nagy ZZ. (ed.) Pediatric ophthalmology. [A könnytermelő és -elvezető rendszer betegségei. In: Nagy ZZs. (szerk.) Gyermekszemészet.] Medicina Könyvkiadó, Budapest, 2017; pp. 111114. [Hungarian]

[30] Repka MX, Melia BM, Beck RW, et al. Primary treatment of nasolacrimal duct obstruction with balloon catheter dilation in children younger than 4 years of age. J AAPOS 2008; 12: 451455 .

[31] Chen PL, Hsiao CH. Balloon dacryocystoplasty as the primary treatment in older children with congenital nasolacrimal duct obstruction. J AAPOS 2005; 9: 546-549.

[32] Lin AE, Chang YC, Lin MY, et al. Comparison of treatment for congenital nasolacrimal duct obstruction: a systematic review and meta-analysis. Can J Ophthalmol. 2016; 51: 34-40.
[33] Repka MX, Melia BM, Beck RW, et al. Primary treatment of nasolacrimal duct obstruction with nasolacrimal duct intubation in children younger than 4 years of age. J AAPOS 2008; 12: $445-450$.

[34] Fayet B, Katowitz WR, Racy E, et al. Pushed monocanalicular intubation: an alternative stenting system for the management of congenital nasolacrimal duct obstructions. J AAPOS 2012; 16: $468-472$.

[35] Engel JM, Hichie-Schmidt C, Khammar A, et al. Monocanalicular silastic intubation for the initial correction of congenital nasolacrimal duct obstruction. J AAPOS 2007; 11: 183-186.

[36] Kaufman LM, Guay-Bhatia LA. Monocanalicular intubation with Monoka tubes for the treatment of congenital nasolacrimal duct obstruction. Ophthalmology 1998; 105: 336-341.

[37] Avram E. Insights in the treatment of congenital nasolacrimal duct obstruction. Rom J Ophthalmol. 2017; 61: 101-106.

[38] Peterson NJ, Weaver RG, Yeatts RP. Effect of short-duration silicone intubation in congenital nasolacrimal duct obstruction. Ophthalmic Plast Reconstr Surg. 2008; 24: 167-171.

[39] Okumuş S, Öner V, Durucu C, et al. Nasolacrimal duct intubation in the treatment of congenital nasolacrimal duct obstruction in older children. Eye 2016; 30: 85-88.

[40] Paul TO, Shepherd R. Congenital nasolacrimal duct obstruction: natural history and the timing of optimal intervention. J Pediatr Ophthalmol Strabismus 1994; 31: 362-367.

[41] Napier ML, Armstrong DJ, McLoone SF, et al. Congenital nasolacrimal duct obstruction: comparison of two different treatment algorithms. J Pediatr Ophthalmol Strabismus 2016; 53: 285-291.

[42] Dortzbach RK, France TD, Kushner BJ, et al. Silicone intubation for obstruction of the nasolacrimal duct in children. Am J Ophthalmol. 1982; 94: 585-590.

[43] Lyon DB, Dortzbach RK, Lemke BN, et al. Canalicular stenosis following probing for congenital nasolacrimal duct obstruction. Ophthalmic Surg. 1991; 22: 228-232.

[44] Welsh MG, Katowitz JA. Timing of silastic tubing removal after intubation for congenital nasolacrimal duct obstruction. Ophthalmic Plast Reconstr Surg. 1989; 5: 43-48.

[45] Červenka S, Matoušek P, Komínek P. Comparing of treatment results of monocanalicular and bicanalicular intubation in inborn lacrimal duct obstruction. [Srovnání léčebných výsledků monokanalikulární a bikanalikulární intubace u vrozené neprůchodnosti slzovodu.] Cesk Slov Oftalmol. 2016; 72: 178-181. [Czech]

[46] Lim CS, Martin F, Beckenham T, et al. Nasolacrimal duct obstruction in children: outcome of intubation. J AAPOS 2004; 8: 466-472.

[47] Fayet B, Racy E, Katowitz J, et al. Insertion of a preloaded Monoka $^{\mathrm{TM}}$ stent for congenital nasolacrimal obstruction: intraoperative observations. A preliminary study. J Fr Ophtalmol. 2019; 42: 248-254.

(Szalai Irén dr.,

Budapest, Mária u. 39., 1085 e-mail: szalai.iren@med.semmelweis-univ.hu)

A cikk a Creative Commons Attribution 4.0 International License (https://creativecommons.org/licenses/by/4.0/) feltételei szerint publikált Open Access közlemény, melynek szellemében a cikk bármilyen médiumban szabadon felhasználható, megosztható és újraközölhető, feltéve, hogy az eredeti szerző és a közlés helye, illetve a CC License linkje és az esetlegesen végrehajtott módositások feltüntetésre kerülnek. (SID_1) 